Original Research Paper

\title{
Effects of Crassocephalum bauchiense Ethanolic Extract on Reproductive Parameters in Rabbit Does Exposed to Potassium Dichromate
}

\author{
1*Chongsi Margaret Mary Momo, ${ }^{2}$ Manfo Tsague Faustin Pascal, ${ }^{1}$ Nyambi Pasima, ${ }^{3}$ Mouokeu Raymond \\ Simplice, ${ }^{1}$ Vemo Bertin Narcisse, ${ }^{1}$ Ngoula Ferdinand and ${ }^{1}$ Tchoumboue Joseph \\ ${ }^{I}$ Department of Animal Production, Faculty of Agronomy and Agricultural Sciences, University of Dschang, Cameroon \\ ${ }^{2}$ Department of Biochemistry and Molecular Biology, Faculty of Science, University of Buea, PO Box 63 Buea, Cameroon \\ ${ }^{3}$ Department of Microbiology and Food Quality Control, Institute of Fisheries and Aquatic Sciences, University of Douala, \\ P.O. Box 7236, Douala, Cameroon
}

\author{
Article history \\ Received: 28-02-2021 \\ Revised: 10-04-2021 \\ Accepted: 10-05-2021 \\ Corresponding Author: \\ Chongsi Margaret Mary Momo \\ Department of Animal \\ Production, Faculty of \\ Agronomy and Agricultural \\ Sciences, University of \\ Dschang, Cameroon \\ Email: margaretchongsi@yahoo.fr
}

\begin{abstract}
The present study was undertaken to evaluate the effects of Hutch leaves Ethanolic Extract (EE) on reproductive parameters, toxicity biochemical markers and oxidative stress indicators in does exposed to Potassium Dichromate (PD). Thirty-six nulliparous sexually mature does of eight months; weighing 2.80-3.00 kg were divided into six groups of six animals, comparable in terms of Body Weight (BW). After mating, group T0 received distilled water, while groups T0-, VC100, EE100, EE200 and EE400 were treated with $40 \mathrm{mg} / \mathrm{BW}$ of PD. Also, group VC100 received 100 $\mathrm{mg} / \mathrm{BW}$ of vitamin $\mathrm{C}$, while groups EE100, EE200 and EE400 received respectively 100, 200 and $400 \mathrm{mg} / \mathrm{BW}$ of EE of hutch leaves. Results showed that urea, creatinine, total cholesterol, alanine aminotransferase and aspartate aminotransferase were significantly higher; with lower total protein levels in T0- concerning the other groups. The follicle-stimulating hormone was significantly lower in T0- as compared to the other groups. Catalase and total peroxidase activities decreased significantly while malondialdehyde and superoxide dismutase increased significantly in T0- than in other groups. From these results, EE of Hutch leaves has protected does against the toxic effects of PD. It can therefore be used to improve female reproduction.
\end{abstract}

Keywords: Ethanolic Extract, Crassocephalum bauchiense, Potassium Dichromate, Rabbit Does, Reproductive Parameters

\section{Introduction}

Reproduction is the essential function that allows species continuity. It improves productivity and perpetuates animal species (Gayrard, 2007). Its perturbation or dysfunction leads to negative consequences on animal productivity (Tamboura et al., 2006). Many factors like ambient temperature, feed type, ration composition, age and exposure to xenobiotics such as drugs and heavy metals can be responsible for this perturbation (Hafez and Hafez, 2005). One of the main mechanisms by which these factors alter reproduction is Oxidative Stress (OS). Oxidative stress occurs when the generation of Reactive Oxygen Species (ROS) and other radical species exceeds the scavenging capacity of Antioxidants (AO) in an organism (Levente, 2016). Oxidative stress is involved in endometriosis, ovarian cancer, polycystic ovary disease, intrauterine growth restriction, abortions, retardation of embryo growth and various other pathologies affecting the female reproductive process (Agarwal et al., 2003), through induction of cell-membrane damage, DNA damage and apoptosis (Jurisicova et al., 1996).

When humans and animals are exposed to heavy metals like iron, copper, cadmium, chromium, mercury, nickel and vanadium contribute OS and carcinogenic effects, resulting in lipid peroxidation, depletion of protein and many other effects (Valko et al., 2005). The harmful action of these heavy metals can however be alleviated by antioxidant substances which scavenge the free radicals and detoxify the organism (Mouokeu et al., 2011). Plants thanks to their diverse bioactive molecules (phenols, flavonoids, alkaloids, tannins, triterpenes) constitute the main source of natural AO molecules, 
which can eliminate or neutralize the deleterious ROS (Shahidi and Naczk, 2003). The anti-oxidant properties of various plants on animal reproduction have been studied. The studied plants include Allium sativum aqueous extracts (Raji et al., 2012), leaves of Tribulus terrestris (Mossa et al., 2015), leaves of Momordica charantia (Adewale et al., 2014), Phoenix dactylifera and Nasturtium officinale (Adaay and Mosa, 2012), essential oils of Syzygium aromaticum (Boudou et al., 2013) and guava leaves (Ngoula et al., 2017). Results obtained were interesting for some researchers while others reported a less significant impact of the extracts on reproductive performance.

Studies are limited to some plants only, yet many other plants can be potential candidates for reproduction improvement in breeding animals. It is the case of Crassocephalum bauchiense. The antioxidant activities of some species of the Crassocephalum genus are well described (Yehouenou et al., 2010). Crassocephalum bauchiense is a species of flowering plant in the Asteraceae family. Phytochemical tests have shown that it contains many antioxidant compounds such as phenols, flavonoids, alkaloids, tannins, triterpenes and sterols (Mouokeu et al., 2011). Thus, it could alleviate the oxidative stress induced by heavy metals on animal reproduction. The current study was therefore initiated to contribute to the improvement of reproduction in farm animals using medicinal plants. More specifically, to contribute to increase in knowledge on available natural sources of antioxidants (Crassocephalum bauchiense) that can fight against oxidative stress induced by exogenous sources like heavy metals (e.g., potassium dichromate) which negatively affect farm animals (e.g., rabbit doe) reproduction.

\section{Materials and Methods}

\section{Animal Material}

Thirty-six adult fertile rabbit-does (New Zealand breed) of 8 months old, weighing $2.8-3.0 \mathrm{~kg}$, produced at
Teaching and Research Farm of the University of Dschang were used. They were treated against external (Exo) and internal (Hemo) parasites by subcutaneous injection of an ivermectin solution $(0.1 \mathrm{ml} / \mathrm{kg} \mathrm{BW})$, repeated after two weeks.

\section{Lodging and Feeding}

Animals were housed in a cement block building with a sheet metal roof, plastered and open 1/3 upper section for ventilation and lighting. They were kept individually in wire cages (galvanized metal, $96 \mathrm{~cm}$ long, $40 \mathrm{~cm}$ wide, $15 \mathrm{~cm}$ high). Each cage was equipped with a feeder and a drinker ( $800 \mathrm{~mL}$ capacity). The building was previously disinfected with a solution of javel water and cresyl (1/2 1 each mixed in 201 water) which was sprayed in the building and all the cages. The active ingredient sodium hypochlorite in javel water denatures proteins in microorganisms and is effective in killing bacteria, fungi and viruses. Cresyl is based on phenolic oil and cresol oil which penetrate treated surfaces faster eliminating bacteria, fungi and viruses. Animals were introduced in the cages two weeks after disinfection. Throughout the trial period, animals received complete feed and water $a d$ libitum. The composition and chemical characteristics of this feed are summarized in Table 1 . Since the animals are experimental, they have to receive the same feed with known composition and chemical characteristics to avoid variation caused by feed.

\section{Plant Material}

Leaves of C. bauchiense (Fig. 1) were collected from Ndop (North West Region of Cameroon). The species had been identified and authenticated at the Cameroon National Herbarium in Yaounde where a voucher specimen was deposited, by referring to sample number 7954/SRF/Cam.

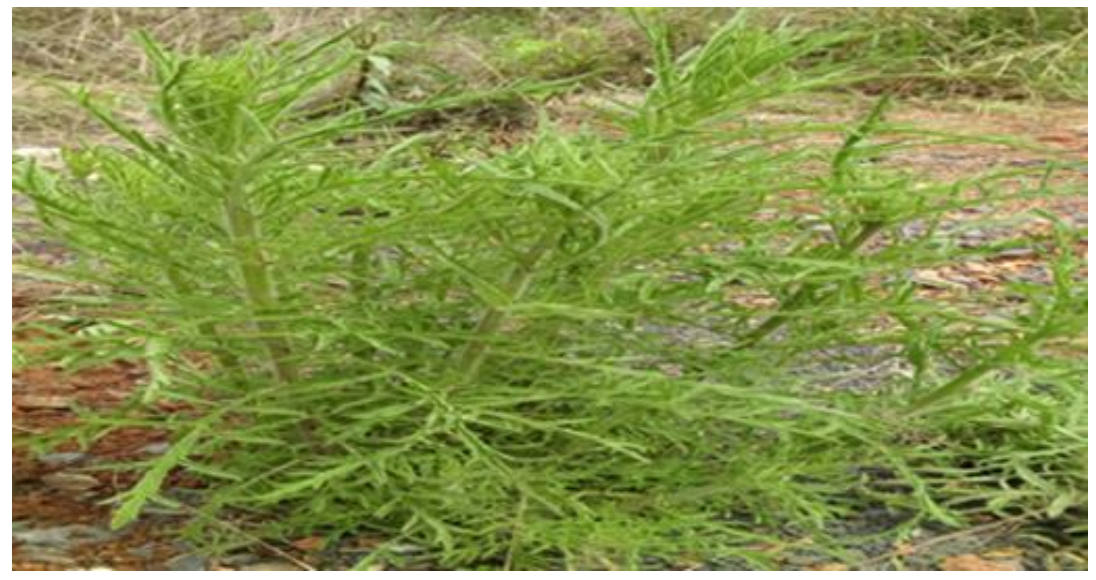

Fig. 1: Entire Crassocephalum bauchiense plant 


\section{Plant Extract Preparation}

The leaves of $C$. bauchiense were dried at room temperature for 10 days and powdered to coarse particles using a grinding mill. Approximately $250 \mathrm{~g}$ of powder was soaked in 1.25 litres of ethanol and left at room temperature for $72 \mathrm{~h}$. The mixture was filtered through a Whatman Filter $\mathrm{N}^{0} 3$ and the filtrate evaporated in the oven at $50^{\circ} \mathrm{C}$ to obtain the ethanolic extract. Solutions of the ethanolic extract of $C$. bauchiense leaves were prepared at different experimental doses by dissolution in distilled water, which served as a vehicle.

\section{Preparation of Potassium Dichromate and Vitamin C solutions}

Potassium dichromate solution was prepared by dissolving a known quantity of potassium dichromate crystals (from Sigma Aldrich, Germany), in distilled water in such a way to obtain a final solution with a concentration of $40 \mathrm{mg} / \mathrm{ml}$. The dose of potassium dichromate $40 \mathrm{mg} / \mathrm{kg}$ body weight used was from a preliminary study carried out by Authors based on values from (Navya et al., 2018).

Soluble tablets (Vitamin C Cevite) containing 500 $\mathrm{mg}$ of vitamin $\mathrm{C}$ each were used. The tablets were dissolved with distilled water to obtain a solution concentrated at $100 \mathrm{mg} / \mathrm{ml}$.

\section{Experimental Design}

Thirty-six fertile rabbit-does were mated with untreated sexually mature males, with a sex ratio of 1: 2 ( $1 \widehat{\delta}$ for 2 ) ) and randomly divided into 6 groups of 6 rabbit-does each, comparable in terms of Body Weight (BW). The 6 groups were assigned different treatments for 27 days post-coïtum, as indicated in Table 2.

On the 28th day post-coïtum, animals were sacrificed for evaluation of fertility parameters, toxicity biochemical markers and oxidative stress indicators. The liver and kidneys were also dissected out and their weights and volumes were determined.

\section{Fertility Traits}

\section{Number and Viability of Fetuses}

The uterus was opened and the number of fetuses obtained by counting. The viability rate was calculated by dividing the number of viable fetuses by the total number of fetuses times 100 .

\section{Resorptions}

The number of corpus luteum was counted on the ovaries. The uterus was steeped in a $2 \%$ sodium hydroxide solution for 10 minutes and the number of implantation sites was counted to determine the number of resorptions as described by (Lim et al., 2010). The number of corpus luteum was compared to the number of implantation sites which permitted to determine the number of preimplantation resorptions using the following formula (Wolterbeek et al., 2004).

\section{Pre-Implantation Resorptions $=$ Number of Corpus Luteum - Number of Implantation Sites}

Post-implantation resorptions were early when only placenta tissues were visible and late when placenta tissues and embryonary tissues were observed. The following formula was used.

Table 1: Composition and chemical characteristics of the feed

\begin{tabular}{lc}
\hline Ingredients & Quantities (\%) \\
\hline Maize & 27.00 \\
Wheat bran & 14.00 \\
Kernel cake & 18.00 \\
Soybeans cake & 5.00 \\
Cotton cake & 4.00 \\
Premix 10\% * & 5.00 \\
Fish meal & 3.00 \\
Palm oil & 2.00 \\
Sea-shells & 1.50 \\
Salt & 0.50 \\
Rice bran & 20.00 \\
Total (kg) Chemical characteristics & 100.00 \\
Metabolisable energy (kcal/kg) & 2435.23 \\
Crude proteins (\% DM) & 16.47 \\
Crude cellulose (\% DM) & 13.65 \\
Calcium (\% DM) & 1.26 \\
Phosphorus (\% DM) & 0.55 \\
Sodium (\% DM) & 0.28 \\
Lysine (\% DM) & 0.83 \\
Methionine (\% DM) & 0.36 \\
\hline Premix $10 \%$ Mixture of vitamins A, B complex, D, K
\end{tabular}

Premix10\% *: Mixture of vitamins A, B complex, D, K and E plus Iron, $\mathrm{Cu}, \mathrm{Zn}, \mathrm{Se}, \mathrm{Mn}$, Methionine, Lysine principally and incorporated at $5 \%$ in the diet

Table 2: Different groups of animals with corresponding treatment

\begin{tabular}{lllllll}
\hline Group & T0 & T0- & VC100 & EE100 & EE200 & EE400 \\
\hline Distilled water (1 ml/kg bw) & 1 & - & - & - & - & - \\
Potassium dichromate (mg/kg bw) & 0 & 40 & 40 & 40 & 40 & 40 \\
Vitamin C (100 mg/ml/kg bw) & - & - & 100 & - & - & - \\
C. bauchiense extract (mg/kg bw) & - & - & - & 100 & 200 & 400 \\
\hline
\end{tabular}

T0: Distilled water; T0-: Potassium dichromate only; VC100: Vitamin C at dose $100 \mathrm{mg} / \mathrm{kg}$ BW; EE100, 200 and 400 : Ethanolic extract of C. bauchiense at doses 100,200 and $400 \mathrm{mg} / \mathrm{kg} \mathrm{BW}$ respectively 
Post-Implantation Resorptions $=$ Number of Implantation Sites - Number of Life Fetuses

\section{Biochemical and Hormonal Analyses}

Blood samples were obtained by cardiac puncture and collected without anticoagulant for biochemical dosages. The blood samples $(5 \mathrm{~mL})$ were obtained between $6: 30$ and 7:30 am by cardiac puncture and stored at $4^{\circ} \mathrm{C}$. Sera were collected $12 \mathrm{~h}$ later for the estimation of biochemical parameters and reproductive hormone levels. The biochemical parameters analyzed from sera were Aspartate aminotransferase (AST), Alanine aminotransferase (ALT), Urea (Ur), Creatinine (Cr), Total Cholesterol (TC) and Total Proteins (TP), measured using a spectrophotometer. The biochemical measurements were performed according to the details given in the instructions of the commercial Chronolab kits (Barcelona, Spain). Follicle-Stimulating (FSH), Luteinizing (LH) and progesterone hormones were measured in sera using AccuDiagTM ELISA kits from OMEGA DIAGNOSTICS LTD (Scotland, England). FSH and LH concentrations were obtained from linear regression equations. For progesterone, concentrations were obtained by projecting optical density of samples read on ELISA meter on calibration curves of progesterone constructed from standard concentrations provided by kits.

\section{Oxidative Stress Markers}

Activities of Superoxide Dismutase (SOD), Total peroxidase, Catalase (CAT) and concentration of Thiobarbituric Acid Reactive Substances (TBARS) in the ovary were measured using the methods proposed by (Misra and Fridovich, 1972; Moron et al., 1979; Aebi, 1984), respectively. Activities of Catalase (CAT), total peroxidase, Superoxide Dismutase (SOD) and level of Thiobarbituric Acid Reactive Substances (TBARS) that is, Malondialdehyde (MDA) in the ovary were measured by spectrophotometer.

\section{Statistical Analysis}

Data were submitted to one-way Analysis of Variance (ANOVA) to test the effects of different treatments on studied parameters. The Duncan test was performed to separate means when there was a significant difference. The results were expressed as mean \pm standard deviation and a limit of significance was fixed at $5 \%$. The software SPSS 20.0 was used for the analysis.

\section{Results}

Effects of Ethanolic Extract of C. Bauchiense on Toxicity Indicators in Rabbit-Does Exposed to Potassium Dichromate

Table 3 summarises the effects of ethanolic extract of $C$. bauchiense on biochemical markers of toxicity in rabbit-does exposed to potassium dichromate. Generally, the sera concentrations of creatinine and urea were significantly $(\mathrm{P}<0.05)$ higher in potassium dichromate-treated animals compared to other groups. Sera concentrations of ALT, AST and total cholesterol increased significantly $(\mathrm{P}<0.05)$ in heavy metal-treated (T0-) rabbit-does compared to other groups. A significant decrease $(\mathrm{P}<0.05)$ was observed in total proteins in T0- does concerning those given distilled water only. Administration of $C$. bauchiense ethanolic extract led to a significant decrease $(\mathrm{P}<0.05)$ in ALT, AST and creatinine and an increase $(\mathrm{P}<0.05)$ in total proteins.

\section{Effects of Ethanolic Extract of C. Bauchiense on Some Reproductive Parameters in Rabbit-does Exposed to Potassium Dichromate}

\section{Fertility Traits of Rabbit-does}

The effects of ethanolic extract of $C$. bauchiense on fertility traits in rabbit-does exposed to potassium dichromate are summarised in Table 4 The numbers of fetuses, corpus luteum, placentas, implantation sites, viable fetuses and pre-implantation resorptions were significantly higher $(\mathrm{P}<0.05)$ in females treated with 200 $\mathrm{mg} / \mathrm{kg} \mathrm{BW}$ of $C$. bauchiense extract compared to other treatments, but no significant difference was noticed. The placenta weight increased insignificantly $(\mathrm{P}>0.05)$ in females receiving an ethanolic extract of $C$. bauchiense referring to $\mathrm{T} 0$ and $\mathrm{T} 0$ - females. The contrary was observed for the number of total resorptions.

\section{Reproductive Hormones}

The effects of ethanolic extract of $C$. bauchiense on serum concentration of reproductive hormones in rabbit-does exposed to potassium dichromate are represented in Table 5.

Sera concentration of FSH increased significantly $(\mathrm{P}<0.05)$ in rabbit-does submitted to the higher doses $(200$ or $400 \mathrm{mg} / \mathrm{kg} \mathrm{BW}$ ) of $C$. bauchiense ethanolic extract compared to potassium dichromate-treated animals (T0-) and rabbit-does receiving distilled water (T0). Serum LH decreased significantly $(\mathrm{P}<0.05)$ in rabbit-does challenged with potassium dichromate only and all doses of $C$. bauchiense ethanolic extract concerning rabbit-does treated with distilled water (T0) and vitamin C. However, progesterone concentrations in serum were comparable among all treatments.

\section{Effects of Ethanolic Extract of C. bauchiense on Oxidative Stress Indicators in Rabbit does Exposed to Potassium Dichromate}

Table 6 summarises the effects of ethanolic extract of C. bauchiense on oxidative stress indicators in rabbitdoes challenged with potassium dichromate. Catalase activity increased significantly $(\mathrm{P}<0.05)$ in rabbit-does co-exposed to potassium dichromate and all doses of $C$. bauchiense ethanolic extract and T0 concerning those receiving only potassium dichromate(T0-). 
Malondialdehyde concentration increased significantly $(\mathrm{P}<0.05)$ in rabbit-does challenged with potassium dichromate only. Administration of $C$. bauchiense ethanolic extract or vitamin $\mathrm{C}$ brought about a significant decrement in the level of this oxidative stress indicator. Total peroxidase activity increased significantly $(\mathrm{P}<0.05)$ in rabbit-does co-exposed to potassium dichromate and all doses of $C$. bauchiense ethanolic extract as compared to those receiving only potassium dichromate(T0-). Superoxide dismutase activity increased significantly $(\mathrm{P}<0.05)$ in rabbit-does challenged with potassium dichromate only with respect does co-exposed to potassium dichromate and all doses of $C$. bauchiense ethanolic extract and T0.

Table 3: Effects of ethanolic extract of $C$. bauchiense on biochemical markers (Mean $\pm \mathrm{SE}$ ) of toxicity in rabbit-does exposed to potassium dichromate

\begin{tabular}{|c|c|c|c|c|c|c|c|}
\hline \multirow{2}{*}{$\begin{array}{l}\text { Biochemical } \\
\text { markers of toxicity }\end{array}$} & \multicolumn{3}{|c|}{ Controls } & \multicolumn{4}{|c|}{ C. bauchiense doses (mg/kg bw) } \\
\hline & T0 & T0- & VC100 & EE100 & EE200 & EE400 & $\mathrm{P}$ \\
\hline \multirow[t]{2}{*}{ Creatinine (mg/dl) } & $1.16 \pm$ & $2.47 \pm$ & $1.58 \pm$ & $1.48 \pm$ & $1.56 \pm$ & $1.48 \pm$ & 0.00 \\
\hline & $0.26^{\mathrm{c}}$ & $0.37^{\mathrm{a}}$ & $0.48^{\mathrm{bc}}$ & $0.17^{\mathrm{bc}}$ & $0.40^{\mathrm{bc}}$ & $0.53^{\mathrm{bc}}$ & \\
\hline \multirow{2}{*}{ Urea $(\mathrm{mg} / \mathrm{dl})$} & $33.72 \pm$ & $46.91 \pm$ & $39.64 \pm$ & $42.89 \pm$ & $43.19 \pm$ & $42.36 \pm$ & 0.37 \\
\hline & $2.20^{\mathrm{b}}$ & $6.78^{\mathrm{a}}$ & $5.26^{\mathrm{ab}}$ & $8.33^{\mathrm{ab}}$ & $6.95^{\mathrm{ab}}$ & $4.11^{\mathrm{ab}}$ & \\
\hline \multirow[t]{2}{*}{ ALT (IU/ml) } & $18.69 \pm$ & $27.09 \pm$ & $15.19 \pm$ & $15.06 \pm$ & $16.50 \pm$ & $19.38 \pm$ & 0.01 \\
\hline & $4.12^{\mathrm{b}}$ & $5.63^{\mathrm{a}}$ & $2.15^{\mathrm{bc}}$ & $3.13^{\mathrm{b}}$ & $2.60^{\mathrm{b}}$ & $2.44^{\mathrm{b}}$ & \\
\hline \multirow[t]{2}{*}{ AST (IU/ml) } & $11.08 \pm$ & $19.95 \pm$ & $13.25 \pm$ & $12.67 \pm$ & $13.48 \pm$ & $11.42 \pm$ & 0.00 \\
\hline & $1.04^{\mathrm{b}}$ & $5.21^{\mathrm{a}}$ & $1.63^{\mathrm{b}}$ & $2.40^{\mathrm{b}}$ & $2.85^{\mathrm{b}}$ & $0.73^{\mathrm{b}}$ & \\
\hline \multirow[t]{2}{*}{ Total proteins (g/dl) } & $4.13 \pm$ & $2.99 \pm$ & $4.93 \pm$ & $3.81 \pm$ & $5.22 \pm$ & $4.19 \pm$ & 0.00 \\
\hline & $0.71^{\mathrm{b}}$ & $0.51^{\mathrm{c}}$ & $0.46^{\mathrm{a}}$ & $0.39^{c}$ & $0.63^{\mathrm{ab}}$ & $0.62^{b c}$ & \\
\hline \multirow[t]{2}{*}{ Total cholesterol (mg/dl) } & $27.56 \pm$ & $42.59 \pm$ & $36.79 \pm$ & $41.19 \pm$ & $40.21 \pm$ & $47.67 \pm$ & 0.00 \\
\hline & $8.32^{\mathrm{c}}$ & $4.34^{\mathrm{a}}$ & $4.43^{\mathrm{ab}}$ & $2.09^{b c}$ & $4.81^{\mathrm{bc}}$ & $5.98^{\mathrm{a}}$ & \\
\hline
\end{tabular}

$\mathrm{a}, \mathrm{b}, \mathrm{c}$ : Values affected with the same letter in the same line are not significantly different $(\mathrm{P}>0.05)$. T0: Distilled water; T0-: Potassium dichromate only; VC100: Vitamin C at dose $100 \mathrm{mg} / \mathrm{kg} \mathrm{BW}$; EE100, 200 and 400: Ethanolic extract of C. bauchiense at doses 100, $200 \mathrm{and} 400 \mathrm{mg} / \mathrm{kg}$ BW respectively

Table 4: Effects of ethanolic extract of $C$. bauchiense on fertility traits (Mean \pm SE) in rabbit-does exposed to potassium dichromate

\begin{tabular}{|c|c|c|c|c|c|c|c|}
\hline \multirow[b]{2}{*}{ Fertility traits } & \multicolumn{3}{|c|}{ Controls } & \multicolumn{4}{|c|}{ C. bauchiense doses (mg/kg bw) } \\
\hline & T0 & T0- & VC100 & EE100 & EE200 & EE400 & $\mathrm{P}$ \\
\hline \multirow[t]{2}{*}{ Number of foetuses } & $7.00 \pm$ & $6.25 \pm$ & $5.67 \pm$ & $7.00 \pm$ & $5.67 \pm$ & $8.00 \pm$ & 0.80 \\
\hline & $0.82^{\mathrm{a}}$ & $1.71^{\mathrm{a}}$ & $1.53^{\mathrm{a}}$ & $0.00^{\mathrm{a}}$ & $1.89^{\mathrm{a}}$ & $2.24^{\mathrm{a}}$ & \\
\hline \multirow[t]{2}{*}{ Number of corpus luteum } & $7.75 \pm$ & $7.50 \pm$ & $6.00 \pm$ & $7.00 \pm$ & $6.67 \pm$ & $8.00 \pm$ & 0.60 \\
\hline & $1.70^{\mathrm{a}}$ & $0.58^{\mathrm{a}}$ & $1.73^{\mathrm{a}}$ & $0.00^{\mathrm{a}}$ & $1.52^{\mathrm{a}}$ & $2.24^{\mathrm{a}}$ & \\
\hline \multirow[t]{2}{*}{ Number of placentae } & $7.75 \pm$ & $7.50 \pm$ & $5.67 \pm$ & $7.00 \pm$ & $6.00 \pm$ & $8.00 \pm$ & 0.65 \\
\hline & $1.71^{\mathrm{a}}$ & $0.58^{\mathrm{a}}$ & $1.53^{\mathrm{a}}$ & $0.00^{\mathrm{a}}$ & $1.65^{\mathrm{a}}$ & $2.24^{\mathrm{a}}$ & \\
\hline \multirow[t]{2}{*}{ Weight of placenta } & $4.87 \pm$ & $4.69 \pm$ & $6.06 \pm$ & $3.59 \pm$ & $5.48 \pm$ & $6.14 \pm$ & 0.04 \\
\hline & $1.44^{\mathrm{a}}$ & $1.58^{\mathrm{a}}$ & $0.74^{\mathrm{a}}$ & $0.38^{\mathrm{b}}$ & $0.97^{\mathrm{ab}}$ & $1.22^{\mathrm{a}}$ & \\
\hline \multirow[t]{2}{*}{ Number of implantation sites } & $7.75 \pm$ & $7.50 \pm$ & $5.67 \pm$ & $7.00 \pm$ & $6.67 \pm$ & $8.00 \pm$ & 0.21 \\
\hline & $1.71^{\mathrm{a}}$ & $0.58^{\mathrm{a}}$ & $1.53^{\mathrm{a}}$ & $0.00^{\mathrm{a}}$ & $1.52^{\mathrm{a}}$ & $2.24^{\mathrm{a}}$ & \\
\hline \multirow[t]{2}{*}{ Number of pre-implantation resorptions } & $0.00 \pm$ & $0.00 \pm$ & $0.33 \pm$ & $0.00 \pm$ & $0.00 \pm$ & $0.00 \pm$ & 0.09 \\
\hline & $0.00^{\mathrm{a}}$ & $0.00^{\mathrm{a}}$ & $0.17^{\mathrm{a}}$ & $0.00^{\mathrm{a}}$ & $0.00^{\mathrm{a}}$ & 0.00 & \\
\hline \multirow[t]{2}{*}{ Number of post-implantation resorptions } & $0.75 \pm$ & $1.25 \pm$ & $0.00 \pm$ & $0.00 \pm$ & $1.00 \pm$ & $0.00 \pm$ & 0.76 \\
\hline & $0.50^{\mathrm{a}}$ & $0.89^{\mathrm{a}}$ & $0.00^{\mathrm{a}}$ & $0.00^{\mathrm{a}}$ & $0.73^{\mathrm{a}}$ & $0.00^{\mathrm{a}}$ & \\
\hline \multirow[t]{2}{*}{ Number of total resorptions } & $0.75 \pm$ & $1.25 \pm$ & $0.33 \pm$ & $0.00 \pm$ & $1.00 \pm$ & $0.00 \pm$ & 0.35 \\
\hline & $0.50^{\mathrm{a}}$ & $0.89^{\mathrm{a}}$ & $0.17^{\mathrm{a}}$ & $0.00^{\mathrm{a}}$ & $0.73^{\mathrm{a}}$ & $0.00^{\mathrm{a}}$ & \\
\hline \multirow[t]{2}{*}{ Number of viable fetuses } & $7.00 \pm$ & $6.25 \pm$ & $5.67 \pm$ & $7.00 \pm$ & $5.67 \pm$ & $8.00 \pm$ & 0.80 \\
\hline & $0.82^{\mathrm{a}}$ & $1.71^{\mathrm{a}}$ & $1.53^{\mathrm{a}}$ & $0.00^{\mathrm{a}}$ & $1.89^{\mathrm{a}}$ & $2.24^{\mathrm{a}}$ & \\
\hline \multirow[t]{2}{*}{ Number of dead fetuses } & $0.00 \pm$ & $0.00 \pm$ & $0.00 \pm$ & $0.00 \pm$ & $0.00 \pm$ & $0.00 \pm$ & 1.00 \\
\hline & $0.00^{\mathrm{a}}$ & $0.00^{\mathrm{a}}$ & $0.00^{\mathrm{a}}$ & $0.00^{\mathrm{a}}$ & $0.00^{\mathrm{a}}$ & $0.00^{\mathrm{a}}$ & \\
\hline
\end{tabular}

T0: Distilled water; T0-: Potassium dichromate only; VC100: Vitamin C at dose $100 \mathrm{mg} / \mathrm{kg} \mathrm{BW}$; EE100, 200 and 400: Ethanolic extract of $C$. bauchiense at doses 100, 200 and $400 \mathrm{mg} / \mathrm{kg}$ BW respectively 
Table 5: Effects of ethanolic extract of $C$. bauchiense on sera concentration of reproductive hormones (Mean \pm SE) in rabbit-does exposed to potassium dichromate

\begin{tabular}{|c|c|c|c|c|c|c|c|}
\hline \multirow{2}{*}{$\begin{array}{l}\text { Serum content in } \\
\text { reproductive hormones }\end{array}$} & \multicolumn{3}{|l|}{ Controls } & \multicolumn{3}{|c|}{ C. bauchiense doses (mg/kg bw) } & \multirow[b]{2}{*}{$\mathrm{P}$} \\
\hline & T0 & T0- & VC100 & EE100 & EE200 & EE400 & \\
\hline \multirow[t]{2}{*}{$\overline{\mathrm{FSH}}(\mathrm{mIU} / \mathrm{ml})$} & $10.67 \pm$ & $4.80 \pm$ & $9.67 \pm$ & $6.25 \pm$ & $9,00 \pm$ & $9.67 \pm$ & 0.00 \\
\hline & $2.07^{\mathrm{a}}$ & $1.3^{\mathrm{c}}$ & $2.08^{\mathrm{a}}$ & $1.5^{\mathrm{bc}}$ & $2.16^{\mathrm{ab}}$ & $1.15^{\mathrm{a}}$ & \\
\hline \multirow[t]{2}{*}{$\mathrm{LH}(\mathrm{mIU} / \mathrm{ml})$} & $5.78 \pm$ & $3.24 \pm$ & $5.53 \pm$ & $3.45 \pm$ & $4.35 \pm$ & $4.65 \pm$ & 0.00 \\
\hline & $0.65^{\mathrm{a}}$ & $0.33^{\mathrm{d}}$ & $0.42^{\mathrm{ab}}$ & $0.85^{\mathrm{cd}}$ & $0.33^{\mathrm{bc}}$ & $0.98^{\mathrm{ab}}$ & \\
\hline Progesterone (ng/ml) & $\begin{array}{l}51.88 \pm \\
1.22^{\mathrm{a}}\end{array}$ & $\begin{array}{l}50.14 \pm \\
1.09^{\mathrm{a}}\end{array}$ & $\begin{array}{l}51.05 \pm \\
3.15^{\mathrm{a}}\end{array}$ & $\begin{array}{l}50.52 \pm \\
2.89^{\mathrm{a}}\end{array}$ & $\begin{array}{l}50.82 \pm \\
1.42^{\mathrm{a}}\end{array}$ & $\begin{array}{l}50.29 \pm \\
1.39^{\mathrm{a}}\end{array}$ & 0.63 \\
\hline
\end{tabular}

T0: Distilled water; T0-: Potassium dichromate only; VC100: Vitamin C at dose $100 \mathrm{mg} / \mathrm{kg} \mathrm{BW}$; EE100, 200 and 400 : Ethanolic extract of C. bauchiense at doses 100, 200 and $400 \mathrm{mg} / \mathrm{kg} \mathrm{BW}$ respectively, FSH: Follicle-Stimulating Hormone LH: Luteinizing Hormone $\mathrm{a}, \mathrm{b}, \mathrm{c}$ : Values affected with the same letter in the same line are not significantly different $(\mathrm{P}>0.05)$

Table 6: Effects of ethanolic extract of $C$. bauchiense on oxidative stress indicators (Mean $\pm \mathrm{SE}$ ) in rabbit-does exposed to potassium dichromate

\begin{tabular}{|c|c|c|c|c|c|c|c|}
\hline \multirow[b]{2}{*}{ Oxidative stress indicators } & \multicolumn{3}{|c|}{ Controls } & \multicolumn{3}{|c|}{ C. bauchiense doses (mg/kg bw) } & \multirow[b]{2}{*}{$\mathrm{P}$} \\
\hline & T0 & T0- & VC100 & EE100 & EE200 & EE400 & \\
\hline \multirow[t]{2}{*}{ CAT $(\mu \mathrm{M} / \mathrm{min} / \mathrm{g}$ of tissue $)$} & $10.02 \pm$ & $5.43 \pm$ & $8.45 \pm$ & $9.03 \pm$ & $8.71 \pm$ & $8.57 \pm$ & \multirow[t]{2}{*}{0.00} \\
\hline & $1.65^{\mathrm{a}}$ & $0.55^{\mathrm{d}}$ & $1.29^{\mathrm{ab}}$ & $0.94^{\mathrm{ab}}$ & $0.90^{\mathrm{ab}}$ & $0.96^{\mathrm{ab}}$ & \\
\hline \multirow[t]{2}{*}{$\operatorname{MDA}(\mu \mathrm{M} / \mathrm{g}$ of tissue $)$} & $0.08 \pm$ & $0.24 \pm$ & $0.11 \pm$ & $0.13 \pm$ & $0.06 \pm$ & $0.03 \pm$ & \multirow[t]{2}{*}{0.00} \\
\hline & $0.02^{\mathrm{c}}$ & $0.05^{\mathrm{a}}$ & $0.02^{\mathrm{b}}$ & $0.01^{\mathrm{b}}$ & $0.01^{\mathrm{cd}}$ & $0.01^{\mathrm{d}}$ & \\
\hline \multirow{2}{*}{$\operatorname{SOD}(\mu \mathrm{M} / \mathrm{min} / \mathrm{g}$ of tissue protein $)$} & $0.38 \pm$ & $0.61 \pm$ & $0.36 \pm$ & $0.52 \pm$ & $0.38 \pm$ & $0.44 \pm$ & \multirow[t]{2}{*}{0.00} \\
\hline & $0.06^{\mathrm{c}}$ & $0.12^{\mathrm{a}}$ & $0.05^{\mathrm{c}}$ & $0.02^{\mathrm{b}}$ & $0.04^{\mathrm{c}}$ & $0.03^{\mathrm{bc}}$ & \\
\hline \multirow[t]{2}{*}{ Total peroxidases ( $\mu \mathrm{M} / \mathrm{g}$ of tissue) } & $36.05 \pm$ & $24.15 \pm$ & $31.94 \pm$ & $48.82 \pm$ & $40.61 \pm$ & $45.54 \pm$ & \multirow[t]{2}{*}{0.00} \\
\hline & $3.42^{\mathrm{cd}}$ & $4.09^{e}$ & $4.82^{\mathrm{d}}$ & $3.71^{\mathrm{ab}}$ & $2.76^{\mathrm{bc}}$ & $4.91^{\mathrm{ab}}$ & \\
\hline
\end{tabular}

T0: Distilled water; T0-: Potassium dichromate only; VC100: Vitamin C at dose $100 \mathrm{mg} / \mathrm{kg} \mathrm{BW}$; EE100, 200 and 400: Ethanolic extract of $C$. bauchiense at doses 100, 200 and $400 \mathrm{mg} / \mathrm{kg}$ BW respectively, CAT: Catalase Activity, MDA: Malondialdehyde, SOD: Superoxide Dismutase $\mathrm{a}, \mathrm{b}, \mathrm{c}, \mathrm{d}, \mathrm{e}$ : Values affected with the same letter in the same line are not significantly different $(\mathrm{P}>0.05)$

\section{Discussion}

Exposure of animals to heavy metals can lead to adverse effects on their health in general and on their reproduction particularly. The kidney and liver are important organs in the evaluation of the toxic potential of a substance (Oloyede et al., 2011). These organs are associated with the metabolism and excretion of toxic substances (Mossa et al., 2015), such as heavy metals. Kidneys perform two major functions: Excrete most of the end products of body metabolism and xenobiotics and control the concentrations of the constituents of the body fluids (Anderson, 1977). Urea and creatinine are markers of renal function in routine analysis. In kidneys, urea is filtered out of the blood by glomeruli and is partially being reabsorbed with water. Creatinine is a breakdown product of creatine phosphate in muscle and is usually produced at a fairly constant rate by the body depending on muscle mass (Zuo et al., 2008). A high level of serum aspartate aminotransferase indicates liver damage that might be contributed to viral hepatitis, cardiac infarction and muscle injury. Serum alanine aminotransferase is more specific to the liver and is thus a better parameter for detecting liver injury (Williamson et al., 1996). Biochemical analyses in the current study showed an increase in activities of alanine aminotransferase, aspartate aminotransferase and concentrations of creatinine, urea and total cholesterol with a decline in total protein levels in rabbit-does challenged with potassium dichromate only compared to those that were co-exposed to the heavy metal and C. bauchiense ethanolic extract or vitamin $C$. Increase in cholesterol level might be due to less utilization of these nutrients at the tissue level. The increase in creatinine and urea could be attributed to the dysfunction of the glomerulus, which are the structures responsible for renal filtration. The increase in sera urea could also be explained by the increase in protein catabolism, due to the high synthesis of the enzyme arginase which intervenes in urea production as this increase in protein catabolism may be associated with a decline in total proteins. Thus, can be attributed to alterations in these organs by the heavy metal, chromium, which can induce oxidative stress. These effects of heavy metals on rabbit-does demonstrate that chromium toxicity is associated with hepatotoxicity and nephrotoxicity. These results agree with earlier findings from (Balakrishnan et al., 2013) who demonstrated that administration of $10 \mathrm{mg} / \mathrm{kg} \mathrm{BW}$ single dose chromium to rats increased cholesterol, ALT, urea, creatinine and MDA levels while total proteins concentration decreased; (Saha et al., 2017) administered 1/25 LD50 potassium dichromate to rats for 90 consecutive days and reported 
increments in liver and kidney weights, cholesterol level, ALT and AST activities with a decrement in plasma protein and albumin concentrations in the animals.

Yousif and Ahmaed (2009) (Yanardag et al., 2007; Soudani et al., 2013; Abbas and Ali, 2007; Zhu et al., 2014) illustrated alteration in animal's health by the other metals lead and cadmium.

These results reflect those of a study on MgO-NPs by (Mangalampalli et al., 2017). A similar type of activities was observed in an acute study with NiO-NPs administration by Dumala et al., 2018 including the findings of Emad and Shimaa, 2016; Ezejiofor and Orisakwe, 2017; Kolakota et al., 2017; Bugata et al., 2019; Jotham et al., 2018.

Interestingly, the results of the present work indicated that when does intoxicated with potassium dichromate were concomitantly administered the plant extract or vitamin $\mathrm{C}$, the above-mentioned parameters were similar to the values of animals that received distilled water only. This suggests the protective effect of the plant extract. $C$. bauchiense is rich in bioactive molecules (phenols, flavonoids, terpenoids) with anti-oxidant properties capable of scavenging ROS induced by potassium dichromate. Results of the present investigation are similar to those of (Mohamed and Saber, 2011), who demonstrated the protective effect of Ambrosia maritima extract in rats exposed to potassium dichromate.

Potassium dichromate exposure induced a decrease in FSH and LH. This might be due to the alteration in the synthesis of the peptide hormones in the pituitary. FSH and $\mathrm{LH}$ are hormones synthesized from proteins captured from the blood. Thus, the reduction in total proteins in blood might contribute to decreases in FSH and LH concentrations in heavy metal-treated rabbit-does. The decrease in levels of these sex hormones recorded in this study is following those registered in female rats exposed to potassium dichromate by (Assasa and Farahat, 2014) suggesting a disruption of steroidogenic function as well as those of (Kareema and Abdul-Hadi, 2016).

However, this is contrary to the findings of (Daku and Salisu, 2016) who reported no significant effect of lead on LH level. Restoration of the levels of these hormones in females co-exposed to the heavy metal and ethanolic extract of $C$. bauchiense support protective effect of the plant extract. As the increase in protein levels was also observed in animals co-exposed to the heavy metal and plant extract, it could be speculated that the extract stimulates the synthesis of the peptide hormones. Similar observations were made following the administration of aqueous extract of Asparagus officinalis roots to female rats at doses of 100 , $200,400 \mathrm{mg} / \mathrm{kg} / \mathrm{bw}$ orally for 28 days (Hojatollah et al., 2016) leading to significant increase in serum levels of GnRH, FSH, LH, estrogen and progestin hormones compared to control group. However, progesterone, which is a steroid hormone produced in the ovaries in response to gonadotrophin (LH) stimulation, remains comparable among all treatments. This is not surprising, since all the females were pregnant and thus the progesterone had reached a certain level to maintain gestation successfully.

Several animal studies provide evidence that hexavalent chromium is a developmental toxicant in rats and mice (ATSDR, 2016). Adverse developmental effects in animals include a greater incidence of postimplantation loss, decreased fetal body weight, reduced ossification and decreased number of live fetuses (ATSDR, 2016). Effects found on female reproductive toxicity in mice and rats include: Lengthening of the estrous cycle; decreased mating and fertility indices; decreased numbers of corpus luteum, implantation sites and live fetuses/litter; and increased frequencies of preand post-implantation loss (Levente, 2016). The present study showed a decrease in the number of resorptions and an increased placenta weight in animals administered the highest dose of $C$. bauchiense. There was also a decrease in the number of corpus luteum, placenta, implantation sites and fetuses in potassium dichromate -treated does as compared to rabbit-does co-exposed to the heavy metal and $C$. bauchiense. The decrease in the number of fetuses may be a consequence of the decrease in the number of implantation sites due to oxidative damage caused by potassium dichromate in the placenta which is susceptible to OS. The improvement of these parameters in the $C$. bauchiense-treated rabbit-does may be attributed to the ROS scavenging capacity of the extract. These results agree with those reported by (Levente, 2016).

Results of this work showed that treatment with potassium dichromate induced OS notified by a significant decrease in CAT and peroxidase activities and increase in MDA and SOD as compared to control values. The decrease in CAT and peroxidase and increase in MDA and SOD might be in response to increased oxidative stress and lipid peroxidation brought about by the presence of the heavy metal. Results obtained for the OS biomarkers reflect those reported by (Mehany et al., 2013; Shati, 2014; Mohamed and Saber, 2011) in rats treated with potassium dichromate. Results revealed that co-administration of $C$. bauchiense leaves ethanolic extract with heavy metal in rabbits does restore CAT, SOD and peroxidase activities and MDA level at the reference values. Kenfack et al. (2018) showed similar results in male guinea pigs receiving $80 \mathrm{mg} / \mathrm{kg}$ bw of acetamiprid for 90 days, concerning the control group. This was similar to the report made by (Vemo et al., 2017) in guinea pigs exposed to cypermethrin (137.5 $\mathrm{mg} / \mathrm{kg} \mathrm{bw}$ ) only, as compared with those co-treated with ethanolic extract of $B$. engleriana leaves.

Ngoumtsop et al. (2017) equally registered close values in Japanese quail receiving $75 \mathrm{mg} / \mathrm{kg}$ bw of 
Antouka Super® in comparison with the control group. The administration of $200 \mathrm{mg} / \mathrm{kg}$ bw of aqueous leaves extracts of Persea americana brought about a restoration of these oxidative stress indicators. These agree with the results of (Oyinloye et al., 2016) after daily administration of $200 \mathrm{mg} / \mathrm{l}$ cadmium to rats for 21 days; and treatment with aqueous extract of Aframomum melegueta (400 mg/kg bw); (Jotham et al., 2018) in rats exposed to diethylnitrosamine (200 mg/kg bw) and treated with Acanthospermum hispidum extracts $(250 \mathrm{mg} / \mathrm{kg} \mathrm{bw})$; (Bugata et al., 2019) in lead intoxicated rats; and (Kader and Kalapuram, 2017) on potassium dichromate exposed rats. These mitigate the oxidative stress induction activities of heavy metals and pesticides on animals and the antioxidant capacities of plant extracts which can be attributed to their bioactive components such as phenols, flavonoids and alkaloids.

The observed normalization trend of CAT, SOD, peroxidase and MDA following $C$. bauchiense leaves ethanolic extract administration could be due to the scavenging effect of this extract. The high potential of phenolic compounds to scavenge radicals might be explained by their ability to donate a hydrogen atom from their phenolic hydroxyl groups. Phytochemical studies by (Mouokeu et al., 2011) showed that C. bauchiense contains phenolic, terpenoids (thymol, carvacrol), flavonoids (diosmetin, luteolin and apigenin), tannins and alkaloids. According to (Singh et al., 2005), the antioxidant activity of plant extracts may not only be attributed to the major compounds, since minor compounds might play a significant role in the antioxidant activity and synergistic effects were reported. Therefore, the possible mechanisms of protective activity of $C$. bauchiense leaves ethanolic extract could arise from the free radical scavenging effects, preventing lipid peroxidation and improving the antioxidant system of the body. The dose of $400 \mathrm{mg} / \mathrm{kg} \mathrm{BW}$ of $C$. bauchiense leaves ethanolic extract could be suggested for use since it is at this dose that most of the parameters were improved.

\section{Conclusion}

Overall, results from the present study suggest that ethanolic extract from $C$. bauchiense leaves exhibit a protective effect against potassium dichromate-induced toxicity in the reproductive function of rabbit does. This was put to evidence by the extract improvement on biochemical markers of toxicity, fertility traits as well as reproductive hormones and oxidative stress indicators. As heavy metals are ubiquitous toxicants, the inclusion of such plant extract in the breeding of the animals may alleviate the toxicity of the xenobiotics, therefore improve on reproductive performances.

\section{Funding}

This research did not receive any specific grant from funding agencies in the public, commercial, or not-forprofit sectors.

\section{Author's Contributions}

Chongsi Margaret Mary Momo: Data collection and interpretation, manuscript final writing, editing and approval.

Manfo Tsague Faustin Pasca: Data collection, data interpretation, designed research methodology.

Nyambi Pasima: Provided the guidelines, data collection and literature review.

Mouokeu Raymond Simplice: Data collection and literature review;

Vemo Bertin Narcisse: Data analysis and literature review.

Ngoula Ferdinand and Tchoumboue Joseph: Conceptualization and supervision of the study.

\section{Ethics}

Experimental protocols used in this study were approved by the Ethical Committee of the Department of Animal Science of the University of Dschang (ECDASUDs 23/02/2015/UDs/FASA/DSAES) and conformed with the internationally accepted standard ethical guidelines for laboratory animal use and care as described in the European Community guidelines; EEC Directive86/609/EEC, of the $24^{\text {th }}$ November 1986.

\section{Data Availability}

The data sets used during the current study are available from the corresponding author upon reasonable request.

\section{References}

Abbas, H. H., \& Ali, F. K. (2007). Study the effect of hexavalent chromium on some biochemical, citotoxicological and histopathological aspects of the Orechromis spp. fish. Pakistan Journal of Biological Sciences: $\quad$ PJBS, 10(22), 3973-3982. https://europepmc.org/article/med/19090268

Adaay, M. H., \& Mosa, A. R. (2012). Evaluation of the effect of aqueous extract of Tribulus terrestris on some reproductive parameters in female mice. Journal Mater Environmental. Science, 3(6), 1153-1162. https://citeseerx.ist.psu.edu/viewdoc/download?doi= 10.1.1.713.4516\&rep=rep1\&type $=$ pdf

Adewale, O. O., Oduyemi, O. I., \& Ayokunle, O. (2014). Oral administration of leaf extracts of Momordica charantia affect reproductive hormones of adult female Wistar rats. Asian Pacific journal of tropical biomedicine, $\quad 4, \quad$ S521-S524. https://doi.org/10.12980/APJTB.4.2014C939 
Aebi, H. (1984). [13] Catalase in vitro. Methods in Enzymology, 105, 121-126. https://doi.org/10.1016/S0076-6879(84)05016-3

Agarwal, A., Saleh, R. A., \& Bedaiwy, M. A. (2003). Role of reactive oxygen species in the pathophysiology of human reproduction. Fertility and Sterility, 79(4), $829-843$. https://doi.org/10.1016/S00150282(02)04948-8

Anderson, B. (1977). Regulation of body fluids. Annual review of physiology, 39(1), 185-200. https://www.annualreviews.org/doi/abs/10.1146/ann urev.ph.39.030177.001153?journalCode=physiol

Assasa, M. F., \& Farahat, M. M. I. (2014). Toxic effect of potassium dichromate on sex hormones and possible protective effect of rice bran oil in female albino rats. Journal Pharmacology. Toxicology, 9, 90-96.

ATSDR. (2016). The Agency for Toxic Substances and Disease Registry. (2000). Atlanta., 1-12. https://www.atsdr.cdc.gov/

Balakrishnan, R., Kumar, C. S., Rani, M. U., Kavita, K., Boobalan, G., \& Reddy, A. G. (2013). Evaluation of protective action of $\alpha$-tocopherol in chromiuminduced oxidative stress in female reproductive system of rats. Journal of Natural Science, Biology and Medicine, $4(1), \quad 87$. https://www.ncbi.nlm.nih.gov/pmc/articles/PMC363 $3310 /$

Boudou, F., Berroukche, A., Bendahmane-Salmi, M., Kandouci, B. A., \& Tou, N. (2013). Ameliorative effects of Syzygium aromaticum essential oil on fertility in male rats exposed to manganese. Advances in sexual medicine, 2013. https://www.scirp.org/html/31990039_37412.htm?pagespeed=noscript

Bugata, L. S. P., Pitta Venkata, P., Gundu, A. R., Mohammed Fazlur, R., Reddy, U. A., Kumar, J. M., ... \& Mahboob, M. (2019). Acute and subacute oral toxicity of copper oxide nanoparticles in female albino Wistar rats. Journal of Applied Toxicology, 39(5), 702-716. http://doi.org/10.1002/jat.3760.3-10.

Daku, A. B., \& Salisu, A. I. (2016). Age-related effects of lead poisoning on sex hormones in adult male Wistar rats. Journal of Physiology and Pathophysiology, 7(4), 23-27.

Dumala, N., Mangalampalli, B., Kalyan Kamal, S. S., \& Grover, P. (2018). Biochemical alterations induced by nickel oxide nanoparticles in female Wistar albino rats after acute oral exposure. Biomarkers, 23(1), 33-43. https://www.tandfonline.com/doi/abs/10.1080/1354 750X.2017.1360943

Emad, A., Hashish, \& Shimaa, A. E. (2016). Protective effect of melatonin against Chromium-induced hepatotoxic and genotoxic effect in Albino rats. Global Veterinaria, 16(4), 323-329.
Ezejiofor, A. N., \& Orisakwe, O. E. (2017). Evaluation of protective effect of aqueous leave extract of Costus afer on female albino Wistar rats exposed to lead acetate. EC Pharmacology and Toxicology, 4(2), 75-92.

Gayrard, V. (2007). Physiology of the reproduction of mammals. National Veterinary School Toulouse 1, 198-99.

Hafez, E. S. E., \& Hafez, S. D. (2005). Erectile dysfunction: anatomical parameters, etiology, diagnosis and therapy. Archives of Andrology, 51(1), 15-31. https://www.tandfonline.com/doi/full/10.1080/1485 010490475147

Hojatollah, K., Hossein, K., Ali, G., Zahra, K., \& Zahra, K. (2016). Effects of aqueous extract from Asparagus officinalis L. roots on hypothalamic-pituitary-gonadal axis hormone levels and the number of ovarian follicles in adult rats. International Journal of Reproduction and BioMededical Research, 14(2), 75-80.

Jotham, Y., Adama, H., Noufou, O., Ernest, N., \& Tata, K. T. (2018). Phytochemistry, antioxidant and hepatoprotective potential of Acanthospermum hispidum DC extracts against diethylnitrosamineinduced hepatotoxicity in rats. Medicines, 5(42). http://doi.org/10.3390/medicines5020042

Jurisicova, A., Varmuza, S., \& Casper, R. F. (1996). Programmed cell death and human embryo fragmentation. MHR: Basic Science of Reproductive Medicine, 2(2), 93-98. https://academic.oup.com/molehr/article/2/2/93/100 7067 ? $\log$ in $=$ true

Kader, A. F., \& Kalapuram, S. P. (2017). Ameliorative effect of Emblica officinalis in potassium dichromate induced toxicity in rats. Eur. Journal Pharmaceutical Medicine Research, 4, 267-274.

Kareema, H. D., \& Abdul-Hadi, A. H. (2016). Effects of Potassium Dichromate on Reproduction and Fertility in Albino Female Mice. International Journal of Pharmacological and Technical Research, 9(8), 205-213.

Kenfack, A., Guiekep, N. A. J., Ngoula, F., Vemo, B. N., Bouli, E. P., \& Pamoal, E. T. (2018). Reproductive toxicity of acetamiprid in male Guinea pig (Cavia porcellus). Journal Animal Science Veterinary Medicine, 3(4), 105-111.

Kolakota, R., Kumar, R. S., \& Patnaik, S. K. (2017). In vitro antioxidant activity and hepatoprotective potential of Ceropegia spiralis against paracetamol induced liver injury. Journal of Applied Pharmaceutical Science, 7(09), 199-206. https://www.japsonline.com/admin/php/uploads/242 5_pdf.pdf 
Levente, S. M. (2016). Neuropathological characterization of fl-pgc-1 $\alpha$-deficient mice implications for mitochondrial encephalopathy. Thesis Doctoral School of Clinical Medicine, University of Szeged, Szeged, Hungary, 61-62. http://doktori.bibl.uszeged.hu/id/eprint/3120/1/Szal\%C3\%A1rdy\%20Le vente\%20Disszert\%C3\%A1ci\%C3\%B3.pdf

Lim, J. H., Kim, S. H., Kim, K. H., Park, N. H., Shin, I. S., Moon, C., ... \& Kim, J. C. (2010). Reproductive and developmental toxicity of amitraz in SpragueDawley rats. Toxicological Research, 26(1), 67-74. https://link.springer.com/article/10.5487/TR.2010.2 6.1 .067

Mangalampalli, B., Dumala, N., \& Grover, P. (2017). Acute oral toxicity study of magnesium oxide nanoparticles and microparticles in female albino Wistar rats. Regulatory Toxicology and Pharmacology, 90, 170-184. http://doi.org/10.1016/j.yrtph.2017.09.005

Mehany, H. A., Abo-youssef, A. M., Ahmed, L. A., Arafa, E. S. A., \& Abd El-Latif, H. A. (2013). Protective effect of vitamin $\mathrm{E}$ and atorvastatin against potassium dichromate-induced nephrotoxicity in rats. Beni-Suef University Journal of Basic and Applied Sciences, 2(2), 96-102. https://doi.org/10.1016/j.bjbas.2013.02.002

Misra, H. P., \& Fridovich, I. (1972). The generation of superoxide radical during the autoxidation of hemoglobin. Journal of Biological Chemistry, 247(21), 6960-6962. https://www.jbc.org/article/S0021-9258(19)446796/fulltext

Mohamed, N. E., \& Saber, R. A. (2011). Effect of aqueous extract of damsissa (Ambrosia maritima) on the biochemical changes induced by potassium dichromate in rats. Journal American Science, 7(3), 234-42.

Moron, M. S., Depierre, J. W., \& Mannervik, B. (1979). Levels of glutathione, glutathione reductase and glutathione S-transferase activities in rat lung and liver. Biochimica et Biophysica Acta (BBA)-General Subjects, 582(1), 67-78. https://doi.org/10.1016/0304-4165(79)90289-7

Mossa, A. T. H., Heikal, T. M., Belaiba, M., Raoelison, E. G., Ferhout, H., \& Bouajila, J. (2015). Antioxidant activity and hepatoprotective potential of Cedrelopsis grevei on cypermethrin induced oxidative stress and liver damage in male mice. BMC Complementary and alternative Medicine, 15(1), 1-10. https://bmccomplementmedtherapies.biomedcentral. com/articles/10.1186/s12906-015-0740-2
Mouokeu, R. S., Ngono, R. A., Lunga, P. K., Koanga, M. M., Tiabou, A. T., Njateng, G. S., ... \& Kuiate, J. R. (2011). Antibacterial and dermal toxicological profiles of ethyl acetate extract from Crassocephalum bauchiense (Hutch.) Milne-Redh (Asteraceae). BMC Complementary and Alternative Medicine, 11(1), 1-7. https://bmccomplementmedtherapies.biomedcentral. com/articles/10.1186/1472-6882-11-43

Navya, K., Chandrasekhar, Y., \& Anilakumar, K. R. (2018). Evaluation of potassium dichromate (K $2 \mathrm{Cr} 2 \mathrm{O} 7)$ induced liver oxidative stress and ameliorative effect of Picrorhiza kurroa extract in Wistar albino rats. Biological Trace Element Research, 184(1), 154-164. https://link.springer.com/article/10.1007/s12011017-1172-2

Ngoula, F., Tekam, M. G., Kenfack, A., Tchingo, C. D. A. T., Nouboudem, S., Ngoumtsop, H., .. \& Tchoumboue, J. (2017). Effects of heat stress on some reproductive parameters of male cavie (Cavia porcellus) and mitigation strategies using guava (Psidium guajava) leaves essential oil. Journal of thermal Biology, 64, 67-72. https://doi.org/10.1016/j.jtherbio.2017.01.001

Ngoumtsop, V. H., Ngoula, F., Kenfack, A., Mutwedu, B. V., Nguemmogne, T. G., Tchoffo, H., ... \& Manjeli, Y. (2017). Effects of Oxidative Stress Induced by Antouka Super (Insecticide)® on Some Reproductive Parameters of Male Japanese Quail (Coturnix coturnix japonica) and Mitigation Strategies Using Aqueous Leaves Extract of Persea americana. Glob Vet, 18(4), 242-249.

Oloyede, A., Okpuzor, J., Omidiji, O., \& Odeigah, P. (2011). Evaluation of sub-chronic oral toxicity of joloo: A traditional medicinal decoction. Pharmaceutical Biology, 49(9), 936-941. https://www.tandfonline.com/doi/full/10.3109/1388 0209.2011.557834

Oyinloye, B. E., Ajiboye, B. O., Ojo, O. A., Musa, H. M., Onikanni, S. A., \& Ojo, A. A. (2016). Ameliorative potential of Aframomum melegueta extract in cadmium-induced hepatic damage and oxidative stress in male Wistar rats. Ameliorative potential of Aframomum melegueta extract in cadmium-induced hepatic damage and oxidative stress in male Wistar Rats., 6(7), 1-6. http://eprints.abuad.edu.ng/245/

Raji, L. O., Fayemi, O. E., Ameen, S. A., \& Jagun, A. T. (2012). The effects of aqueous extract of allium sativum (garlic) on some aspects of reproduction in the female albino rat (wistar strain). Global Veterinaria, 8(4), 414-20.

Saha, J., Choudhuri, S., \& Choudhuri, D. (2017). Effect of subchronic exposure to chromium on hematological and biochemical parameters of male albino rat. Asian Journal Pharmacology Clin. Research, 10, 2017. 
Shahidi, F., \& Naczk, M. (2003). Phenolics in food and nutraceuticals. CRC press. ISBN-10: 0203508734.

Shati, A. A. (2014). Ameliorative effect of vitamin E on potassium dichromate-induced hepatotoxicity in rats. Journal of King Saud University-Science, 26(3), 181-189. https://doi.org/10.1016/j.jksus.2013.12.001

Singh, V. K., Dixit, P., \& Saxena, P. N. (2005). Cybil induced hepatobiochemical changes in wistar rats. Journal of Environmental Biology, 26(4), 725-727. https://europepmc.org/article/med/16459564

Soudani, N., Bouaziz, H., Sefi, M., Chtourou, Y., Boudawara, T., \& Zeghal, N. (2013). Toxic effects of chromium (VI) by maternal ingestion on liver function of female rats and their suckling pups. Environmental Toxicology, 28(1), 11-20. https://pubmed.ncbi.nlm.nih.gov/21374791/

Tamboura, H. H., Bayala, B., Pellicer, M. T., Zongo, D., Traoré, A., Ouédraogo, L., Malpaux, B., \& Sawadogo, L. (2006). Estrogenic effects of macerated aqueous extracts of leaves of Holarrhena floribunda (G. Don) in ovariectomised rat. Base, 10(3), 173-180.

Valko, M. M. H. C. M., Morris, H., \& Cronin, M. T. D. (2005). Metals, toxicity and oxidative stress. Current Medicinal Chemistry, 12(10), 1161-1208. https://www.ingentaconnect.com/content/ben/cmc/2 005/00000012/00000010/art00003

Vemo, B. N., Kenfack, A., Ngoula, F., Nantia, E. A., Kodjio, N., Guiekep, A. J. N., ... \& Teguia, A. (2017). Effects of ethanol extract of Bersama engleriana leaves on oxidative stress and reproductive parameters in male Guinea pig (Cavia porcellus) exposed to cypermethrin. International Journal of Biological and Chemical Sciences, 11(5), 2243-2253. https://www.ajol.info/index.php/ijbcs/article/view/1 64766

Williamson, E. M., Okpako, D. T., \& Evans, F. J. (1996). Selection, Preparation and Pharmacological Evaluation of Plant Material, Volume 1 (Vol. 1). John Wiley \& Sons. ISBN-10: 0471942170.
Wolterbeek, A. P. M., Roberts, A., Korte, H., Unkila, M., \& Waalkens-Berendsen, D. H. (2004). Prenatal developmental toxicity study with 7hydroxymatairesinol potassium acetate (HMRlignan) in rats. Regulatory Toxicology and Pharmacology, 40(1), 1-8. https://doi.org/10.1016/j.yrtph.2004.04.001

Yanardag, R., Ozsoy-Sacan, O., Ozdil, S., \& Bolkent, S. (2007). Combined effects of vitamin C, vitamin E and sodium selenate supplementation on absolute ethanol-induced injury in various organs of rats. International Journal of Toxicology, 26(6), 513-523. https://journals.sagepub.com/doi/full/10.1080/10915 810701707296

Yehouenou, B., Wotto, V., Bankole, H., Sessou, P., Noudogbessi, J. P., \& Sohounhloue, D. (2010). Chemical study and antimicrobial activities of volatile extracts from fresh leaves of crassocephalum rubens(juss \& jack) s. moore against food-borne pathogens. Scientific Study \& Research: Chemistry \& Chemical Engineering, Biotechnology, Food Industry, 11(3), 341-349.

Yousif, A. S., \& Ahmed, A. A. (2009). Effects of cadmium $(\mathrm{Cd})$ and lead $(\mathrm{Pb})$ on the structure and function of thyroid gland. African Journal of Environmental Science and Technology, 3(3), 78-85. https://www.academia.edu/download/46975613/Effe cts_of_Cadmium_Cd_and_Lead_Pb_on2016070327131-1jwskd6.pdf

Zhu, H., Jia, Y., Cao, H., Meng, F., \& Liu, X. (2014). Biochemical and histopathological effects of subchronic oral exposure of rats to a mixture of five toxic elements. Food and Chemical Toxicology, 71, 166-175. https://doi.org/10.1016/j.fct.2014.06.005

Zuo, Y., Wang, C., Zhou, J., Sachdeva, A., \& Ruelos, V. C. (2008). Simultaneous determination of creatinine and uric acid in human urine by high-performance liquid chromatography. Analytical Sciences, 24(12), 1589-1592.

https://www.jstage.jst.go.jp/article/analsci/24/12/24_ 12_1589/_article/-char/ja/ 